\title{
A VEGETAÇÃO NATIVA EM SANTA MARIA ${ }^{1}$
}

\author{
JOSÉNEWTONCARDOSOMARCHIORI ${ }^{2}$
}

\section{RESUMO}

A vegetação natural do município de Santa Maria é analisada em suas unidades constituintes, à luz de subsídios históricos e da ocupação do espaço regional.

Palavras-chave: Vegetação natural, Florística, Santa Maria, Rio Grande do Sul, Brasil.

\section{SUMMARY}

[Native vegetation in Santa Maria, Rio Grande do Sul, Brazil].

The natural vegetation in the municipality of Santa Maria (Rio Grande do Sul state, Brazil) is analysed in its phytogeographic units, with the aid of regional history and land occupation.

Key words: Natural vegetation, Floristics, Santa Maria, Rio Grande do Sul, Brazil.

\section{INTRODUÇÃO}

A vegetação nativa de Santa Maria, como em todo o Rio Grande do Sul, compreende duas unidades básicas - campos e florestas -, muito distintas entre si sob os pontos de vista fisionômico, estrutural e florístico. Esta dicotomia no espaço regional não constitui novidade, figurando na literatura desde os trabalhos pioneiros de Lindman ${ }^{3}$ e Hermann von Ihering ${ }^{4}$, bem como na obra de Balduíno Rambo, fitogeógrafo que postulou a existência de um verdadeiro "hiato sistemático" entre florestas e campos no Estado $^{5}$.

Recebido em 14/3/2008 e aceito para publicação em 30/ 6/2008.

2 Engenheiro Florestal, Dr., bolsista de Produtividade em Pesquisa do CNPq, Professor Titular do Departamento de Ciências Florestais, Universidade Federal de Santa Maria, CEP 97105-900, Santa Maria (RS). balduinia@mail.ufsm.br

3 LINDMAN, C. A. M. A vegetação no Rio Grande do Sul (Brasil Austral). Porto Alegre: Echenique Irmãos \& Cia., 1906. 356 p.

4 IHERING, H. von. A distribuição de campos e mattas no Brazil. Revista do Museu Paulista, São Paulo, v. 7, p. 125-178, 1907.

5 A expressão foi originalmente utilizada em publicação sobre a família das Leguminosas (RAMBO, B. Estudo comparativo das leguminosas riograndenses. Anais Botânicos do Herbário "Barbosa Rodrigues", Itajaí, n. 5, p. $107-184,1953)$.
De causa diversa, mas igualmente importantes, são as alterações produzidas direta ou indiretamente pelo Homem, sobretudo a partir da entrada dos primeiros jesuítas no Tape $^{6}$, em meados do século XVII. A introdução do gado e, posteriormente, a colonização produziram transformações de grande magnitude na paisagem sul-rio-grandense. Mesmo assim, ao olhar atento do pesquisador, a distribuição original de campos e florestas, bem como sua estrutura e composição florística, podem ainda hoje ser reconhecidas, com suficiente clareza.

Fruto do trabalho de inúmeros pesquisadores, o estudo da vegetação regional teve início na primeira metade do século XIX, com a chegada dos primeiros viajantes-naturalistas. $\mathrm{O}$ material botânico aqui recolhido, conservado em importantes herbários do mundo, foi estudado e re-estudado por sucessivas gerações de pesquisadores, fornecendo um robusto suporte para o atual conhecimento da flora e vegetação nativas. Igualmente importantes foram as pesquisas desenvolvidas posteriormente, em instituições brasileiras voltadas às ciências naturais.

\footnotetext{
6 Constante na literatura jesuítica, o termo, que significa "povoação grande", foi o primeiro atribuído ao espaço geográfico correspondente ao atual Rio Grande do Sul.
} 
Antes da análise da vegetação propriamente dita, convém esboçar-se, nem que seja em rápido apanhado, a evolução do conhecimento científico e seus principais atores na região central do Estado.

\section{SUBSÍDIOS HISTÓRICOS}

Localizada no centro geográfico do Rio Grande do Sul, Santa Maria figurou, desde o início, na rota de alguns dos mais importantes naturalistas que percorreram a Província e Estado, a partir de meados do século XIX.

O primeiro deles, certamente, foi Auguste de Saint-Hilaire ${ }^{7}$. Vindo das Missões, o francês chegou à "Capela de Santa Maria" em 9 de abril de 1821, partindo, em direção à capital, dois dias mais tarde. Além de coletas botânicas, seu principal objetivo, Saint-Hilaire deixou-nos, em sua "Viagem ao Rio Grande do Sul", um dos relatos mais valiosos já publicados sobre a região.

Dois anos após a visita de Saint-Hilaire, chegava Friedrich Sellow ${ }^{9}$ a Santa Maria, na qualidade de naturalista do Museu Nacional do Rio de Janeiro. Vindo de Montevidéu, o botânico alemão entrou no Rio Grande do Sul por terras do

7 Natural de Orléans (4/10/1779), Augustin-François-César Prouvensal de Saint-Hilaire faleceu em Turpinière (França), em 30/9/1853. Membro da embaixada do Conde de Luxemburgo, Saint-Hilaire chegou ao Brasil em 1/6/1816, percorrendo, ao longo de seis anos, cerca de 2.500 léguas pelo interior do país. $\mathrm{O}$ material botânico reunido nessas viagens renderam-lhe notáveis publicações científicas, salientando-se a Flora Brasilica Meridionalis (1825), que abriu-lhe as portas da "Academia de Ciências" da França. Suas coletas de plantas brasileiras estimam-se em 30.000 exemplares, pertencentes a mais de 7.600 espécies.

8 Publicada originalmente em francês (1887), essa obra mereceu duas traduções para o português. A mais antiga, realizada por Leonam de Azeredo Penna, restringe seu conteúdo ao Rio Grande do Sul, deixando de lado o texto relativo ao moderno Uruguai. A tradução de Adroaldo Mesquita da Costa, além de mais completa (inclui o texto referente à Cisplatina), distingue-se, ainda, pela maior fidelidade ao original.

9 Friedrich Sellow nasceu em Potsdam (12/3/1789) e faleceu no Brasil, aos 42 anos de idade. atual município de Livramento, em 24 de março de 1823, passando em seguida por Santa Maria e São Martinho, a caminho de Porto Alegre. Morto por afogamento no rio Mucuri (1831), o desventurado naturalista não teve tempo para publicações científicas e relatar suas vivências no interior do Brasil, ${ }^{10}$ motivo pelo qual seu nome continua praticamente desconhecido fora dos meios acadêmicos. O material botânico por ele reunido, que inclui exsicatas de Santa Maria e arredores, supera, inclusive, o de SaintHilaire, ${ }^{11}$ convertendo-o no coletor de espécies-novas mais citado pela monumental Flora Brasiliensis. ${ }^{12}$ Como prova do trabalho infatigável deste viajante-naturalista, cabe informar que apenas no Herbário de Santiago do Chile encontram-se mais de 120 "tipos" de Mirtáceas, entre espécies e variedades ${ }^{13}$, por ele coletadas no Brasil e Uruguai. ${ }^{14}$

A esses dois cientistas seguiram-se Arsène Isabelle $^{15}$ e Robert Avé-Lallemant, autores de relatos que figuram entre os mais notáveis na estante sul-rio-grandense de viajantes.

${ }^{10} \mathrm{O}$ moderno Uruguai, ao tempo da viagem de Friedrich Sellow, ainda era a Província Cisplatina, pertencente ao Brasil. Não causa estranheza, portanto, que nas etiquetas de suas exsicatas botânicas apareça, com freqüência, o nome de "Montevideo", como referência geográfica.

${ }^{11}$ Somente para o Botanisches Museum (Berlim), Sellow enviou 51.480 exsicatas, pertencentes a mais de 11.700 espécies botânicas; boa parte desse material, infelizmente, perdeu-se no incêndio do referido Museu, por ocasião da Segunda Guerra Mundial.

${ }^{12}$ Iniciada por Martius e terminada por Urban, a Flora Brasiliensis inclui a descrição de milhares de espécimes coletados por Friedrich Sellow.

${ }^{13}$ Cabe salientar que muitos desses binômios recaíram, com o tempo, em sinonímia.

${ }^{14}$ KAUSEL, E. Los tipos de Mirtáceas extranjeras conservados en el Herbário de Santiago. Revista Universitária (Universidad Católica de Chile), Santiago, v. 35, n. 1, p. $135-146,1950$.

15 Autor de uma "Viagem ao Rio Grande do Sul (18331834)", Arsène Isabelle nasceu no Havre (França, 1807) e faleceu por suicídio, em sua terra natal, a 13/1/1888. Comerciante de profissão, mas inclinado às ciências naturais, viajou para a América do Sul em 1830, estabelecendo-se inicialmente em Buenos Aires e, mais tarde, em Montevidéu. 

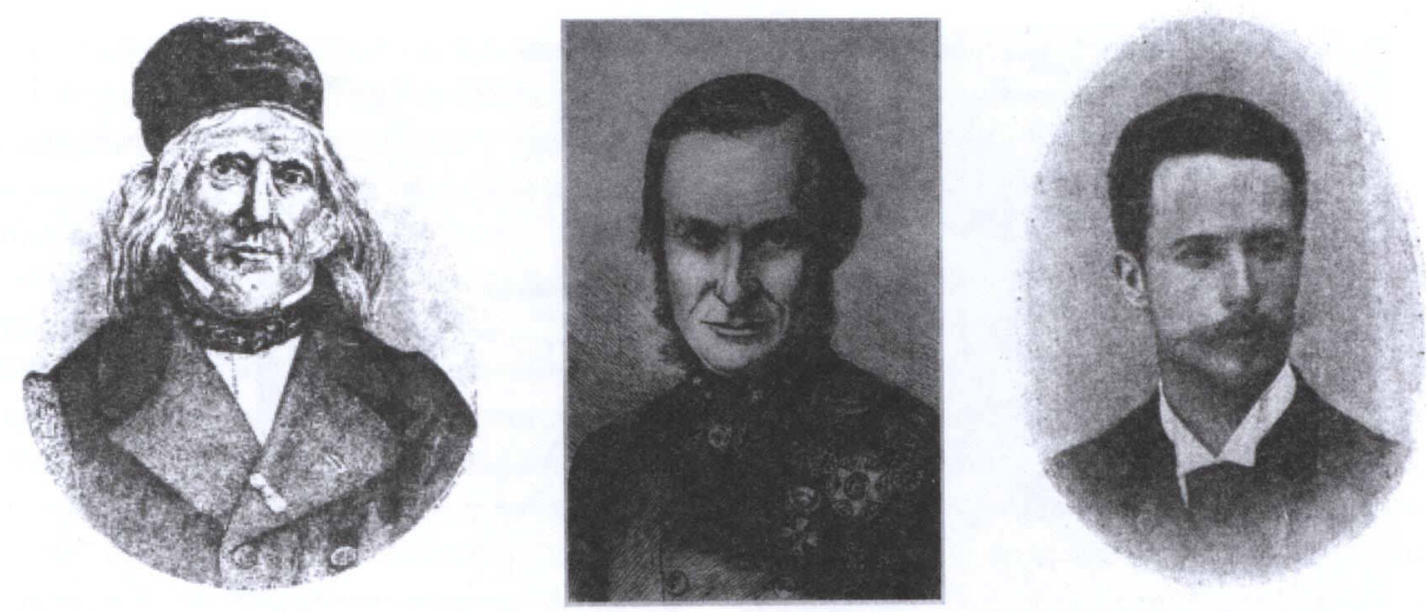

FIGURA 1 - Três viajantes-naturalistas do século XIX: Auguste de Saint-Hilaire, Robert Avé Lallemant e Carl Lindman (da esquerda para a direita).

Com as limitações de um naturalista-amador, Isabelle chegou a Santa Maria a primeiro de março de 1830, vindo de Buenos Aires e a caminho de Porto Alegre. Além de coletas botânicas, infelizmente perdidas com o tempo, Isabelle foi um dos pioneiros no registro de "troncos de árvores fósseis" na região de Santa Maria.

Médico de notável cultura, Robert AvéLallemant ${ }^{16}$ viajou pelo Rio Grande do Sul no ano de 1858, após muitos anos de residência no Rio de Janeiro. Mesmo não sendo naturalista, o relato de Avé-Lallemant merece destaque por suas referências a aspectos da fitogeografia regional. É o caso do registro sobre o extinto pinhal de Itaara, próximo a Santa Maria, revelador de brilho literário e agudeza de observação:

"Os enormes pinheiros elevam-se de cem a cento e vinte pés de altura. A grande impres-

\footnotetext{
${ }^{16}$ Ao contrário do sugerido pelo acento francês do nome, Robert Avé-Lallemant nasceu em Lübeck (Alemanha), em 1812. Após estudos superiores em Berlim e Paris, doutorou-se pela Universidade de Kiel (1837), viajando no ano seguinte para o Brasil. Durante 17 anos trabalhou como médico no Rio de Janeiro. Após breve retorno à terra natal, deu início às longas e proveitosas excursões pelo interior do Brasil, oportunidade que rendeu-lhe material para importantes relatos de viagem.
}

são que me causaram foi ainda aumentada pelas elegantes palmeiras que se erguem entre eles. Poderia dizer que debalde procuram as palmeiras alcançar a altura das araucárias. Apenas a metade da altura dos sombrios pinheiros atingem as lindas árvores vizinhas. Neste pinetum e palmetum ${ }^{17}$ entrega-se o peregrino nórdico de bom grado aos sentimentos, despertados com mais vivacidade pelo primeiro do que pelo segundo. Com muito prazer escuta o vento que sopra na floresta. Enquanto os folíolos das palmeiras sussurram loquazmente entre si, sibila o vento nas copas das araucárias, à maneira melancólica do norte, e em vão tenta abafar o dourado sol da tarde de linda coloração com os tons de grave tristeza no alto das sombrias coníferas". ${ }^{18}$

${ }^{17}$ Com admirável acerto para a época, Avé-Lallemant logrou caracterizar a vegetação, de acordo com a moderna concepção de "Floresta Mista": as "florestas com Araucária", em verdade, baseiam-se na mistura de elementos florísticos próprios de clima temperado (Antárticos, Holárticos e Andinos), sugeridos na palavra pinetum, com elementos oriundos da floresta latifoliada, resumidos sob o termo palmetum, uma alusão ao gerivá (Syagrus romanzoffianum).

18 AVE-LALLEMANT, R. Viagem pelo sul do Brasil no ano de 1858. Rio de Janeiro: Instituto Nacional do Livro, 1953. p. 204-205). 

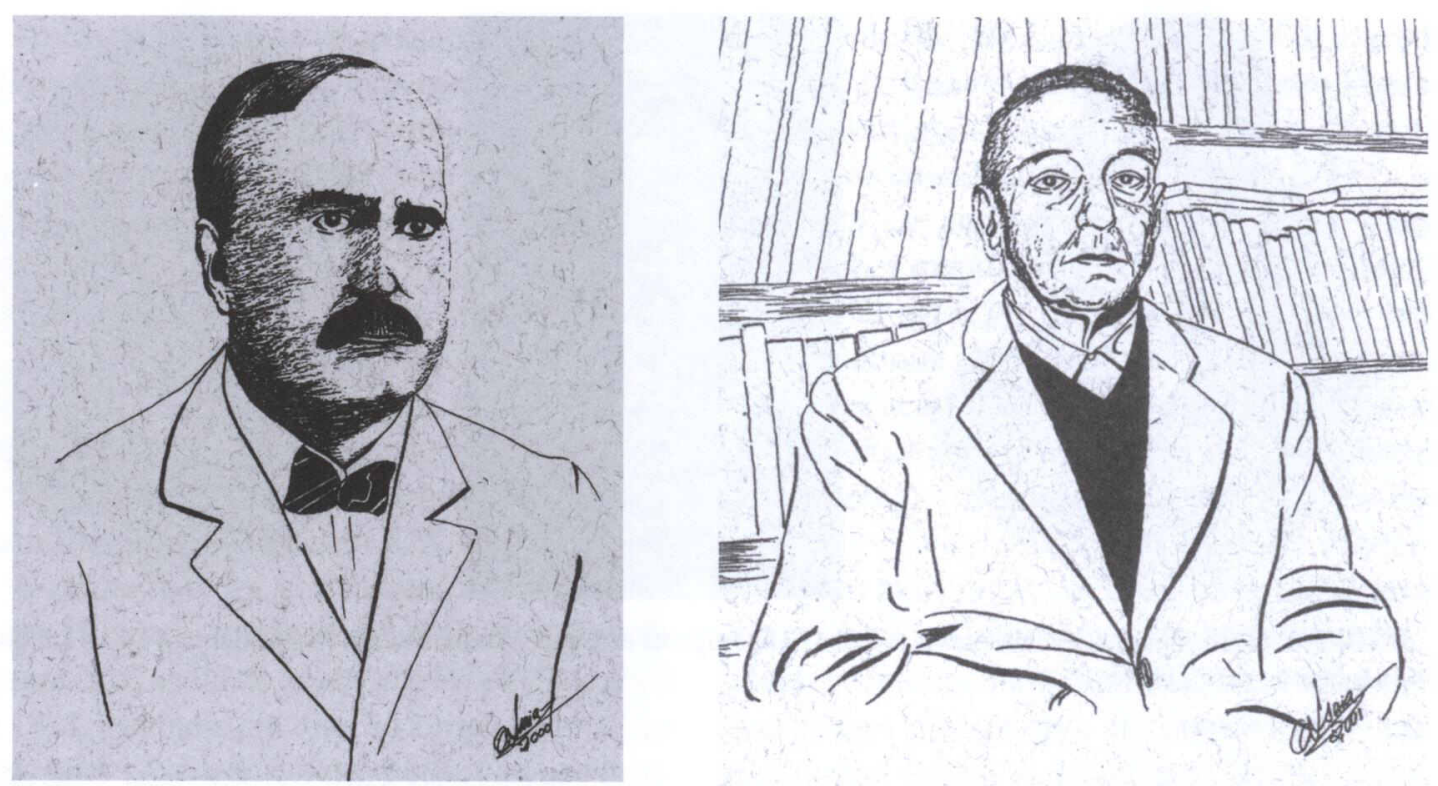

FIGURA 2 - Dois naturalistas do século XX: Guilherme Rau (à esquerda) e Romeu Beltrão (à direita), em bicos-de-pena de Antônio Isaia.

Integrantes da Expedição Regnelliana ${ }^{19}$, Lindman $^{20}$ e Malme ${ }^{21}$ realizaram coletas botânicas em dois períodos na região de Santa Maria: de 4 a 23 de março de 1893 , em sua viagem de Cachoeira do Sul para Ijuí (via Silveira Martins), e de 27 de abril a 7 de maio do mesmo ano, no retorno de Ijuí para Porto Alegre, via São Martinho. Integrantes do corpo científico do Museu de Estocolmo, os eminentes botânicos viram-se forçados a abandonar o Estado por motivos de segurança, devido à Revolução de 1893. Malme retornou ao Rio Grande do Sul (e a Santa Maria) em 1902, para novas coletas botânicas. Lindman, embora não tenha

\footnotetext{
${ }^{19}$ Iniciativa de Anders Fredrik Regnell, visava a auxiliar botânicos suecos interessados na investigação da flora brasileira. Com vistas à da cura da tuberculose, doença por ele contraída, Regnell emigrou para o Brasil (Poços de Caldas - Minas Gerais), onde trabalhou como médico por quase 50 anos, amealhando pequena fortuna que destinou à pesquisa botânica.

${ }^{20}$ Carl Axel Magnus Lindman nasceu em Halmstad (sul da Suécia), em 6/4/1856, e faleceu em Estocolmo, em 21/6/ 1928. Doutor em Botânica pela famosa Universidade de Uppsala (1886), foi pesquisador do Museu Nacional de Estocolmo.
}

retornado, deixou-nos uma das obras fundamentais sobre a vegetação sul-rio-grandense. Publicada originalmente na Suécia (1900), A vegetação do Rio Grande do Sul ${ }^{22}$ inclui importantes referências sobre os arredores da cidade.

Em setembro de 1910, chegava Wilhelm $\operatorname{Rau}^{23}$ a Santa Maria, depois de clinicar em Porto Alegre e Caçapava do Sul. Radicado definitivamente na cidade, o médico alemão encontrara, finalmente, um campo fecundo para a sua inata vocação às ciências naturais, chegando, inclusi-

${ }^{21}$ Gustav Oskar Andersson Malme nasceu em Stora Malm (Suécia), em 24/10/1864, e faleceu em Estocolmo, em 5/ $3 / 1937$. Doutor pela Universidade de Uppsala, notabilizou-se como taxonomista vegetal.

${ }^{22}$ Traduzida para o português por Alberto Löfgren, a obra teve sua primeira edição em 1906 (Livraria Universal, de Echenique Irmãos \& Cia., Porto Alegre). A segunda, de 1974, foi um co-edição entre a Editora da Universidade de São Paulo e a Livraria Itatiaia.

${ }^{23}$ Natural de Ludwigshafen, Palatinado (30/7/1874), faleceu em Santa Maria (11/5/1953). Médico pelas universidades de Berlim, Munique e Bonn, deixou importantes contribuições à Paleontologia, Geologia e Botânica do Rio Grande do Sul. 
ve, embora por curto período, a lecionar Botânica Aplicada à Farmácia, na Faculdade de Santa Maria. ${ }^{24}$ Igualmente dedicado à Geologia e Paleontologia, a predileção pela Scientia Amabilis demonstra-se no rico acervo por ele reunido, do qual ainda subsistem numerosas exsicatas no Herbário SMDB. ${ }^{25}$

Romeu Beltrão, ${ }^{26}$ em dois alentados trabalhos florísticos, vindos a lume em $1962^{27}$ e $1965^{28}$, listou 1073 espécies fanerogâmicas para o município de Santa Maria, entre nativas e cultivadas, distribuídas em 113 famílias botânicas. No capítulo introdutório ao primeiro destes catálogos, o autor ressalta a contribuição de Balduíno Rambo, Diego Legrand, Irmão Teodoro Luiz, Alarich Schultz e F. C. Hoehne na identificação de exsicatas por ele coletadas. Apesar das inevitáveis falhas, perceptíveis em exame mais detalhado, e das numerosas espécies agregadas posteriormente à flora regional, as duas publicações persistem como basilares para o conhecimento da flora local.

A criação de novos cursos na Universidade Federal de Santa Maria, notadamente de Agronomia, Biologia e Engenharia Florestal, trouxe novo alento à pesquisa botânica e fitossociológica. Além de numerosas publicações sobre a vegetação e flora regionais, cabe salien-

${ }^{24}$ A Faculdade de Farmácia foi a precursora da Universidade Federal de Santa Maria.

${ }^{25}$ Herbário do Departamento de Biologia, da Universidade Federal de Santa Maria, sucessor do HFFSM (Herbário da Faculdade de Farmácia de Santa Maria).

${ }^{26}$ Filho de Santa Maria, Romeu Calderan Beltrão nasceu a 26/6/1913 e faleceu na mesma cidade, em 16/11/1977. Médico, jornalista, professor universitário, historiador e naturalista, a bibliografia produzida por Romeu Beltrão destaca-se pela fecundidade, qualidade de texto e diversidade de temas.

${ }^{27}$ BELTRÃO, R. Flórula fanerogâmica do município de Santa Maria, RS, Brasil (Primeiro Catálogo). Boletim do Instituto de Ciências Naturais da Universidade de Santa Maria, Santa Maria, n. 1, p. 3-63, 1962.

${ }^{28}$ BELTRÃO, R. Flórula fanerogâmica do município de Santa Maria, RS, Brasil (Primeiro Suplemento). Boletim do Instituto de Ciências Naturais da Universidade de Santa Maria, Santa Maria, n. 2, p. 115-151, 1965. tar, atualmente, o suporte à pesquisa proporcionado pelos herbários SMDB e HDCF. ${ }^{29}$

\section{TRANSFORMAÇÕES NATURAIS E ANTRÓPICAS}

Como visto anteriormente, a vegetação original de Santa Maria reúne campos e florestas. Muito distintas entre si, sob os aspectos fisionômico-estrutural, fitoecológico e florístico, estas duas unidades encontram-se em permanente competição no espaço regional - e sob forte influência do clima -, que sofreu oscilações marcantes ao longo do Quaternário ${ }^{30}$. O Homem e animais domésticos, por sua vez, também deixaram importantes impactos no quadro da vegetação original.

Ao final do Pleistoceno ${ }^{31}$, sob a vigência de um período glacial ${ }^{32}$, as áreas florestais reduziam-se a fragmentos localizados em sítios mais abrigados e favorecidos no tocante ao suprimento de água. Com o aquecimento e umidificação, verificados no Holoceno ${ }^{33}$, criaram-se condições propícias ao avanço da floresta sobre áreas campestres, seja pela expansão dos refúgios florestais pleistocênicos, baseados em elementos florísticos extratropicais ${ }^{34}$, seja pela entrada de uma diversificada e vigorosa corrente florística

${ }^{29}$ Herbário do Departamento de Ciências Florestais (Universidade Federal de Santa Maria), especializado na flora silvática regional.

${ }^{30}$ Período da era Cenozóica, que corresponde aos últimos 1,6 milhões de anos.

${ }^{31}$ Época do período Quaternário e era Cenozóica, situado entre 1,6 milhões de anos e 10.000 anos antes do presente.

${ }^{32}$ A glaciação de Würm (Wisconsin) alcançou o máximo entre 21.000 e 18.000 anos atrás, marcando o término do Pleistoceno. Acredita-se que o nível dos oceanos tenha baixado entre 120 e $140 \mathrm{~m}$, em relação ao nível atual, enquanto capas de gelo cobriam o sul dos Andes, bem como altas latitudes (BOLZON, R. T., MARCHIORI, J. N. C. A vegetação no sul da América: perspectiva paleoflorística. Ciência \& Ambiente, Santa Maria, n. 24, p. 21, 2002).

${ }^{33}$ Época do período Quaternário e era Cenozóica, correspondente aos últimos 10.000 anos antes do presente.

${ }^{34}$ Por elementos extratropicais, quer-se referir ao conjunto de elementos florísticos antárticos, holárticos e andinos. 
de cunho tropical, oriunda de baixas latitudes, mediante duas rotas imigratórias: a litorânea, pelas escarpas das serras do Mar e Geral, e a interiorana, via bacia dos rios Paraná e Uruguai.

No Rio Grande do Sul, o limite brusco entre florestas e campos pode ser explicado pela biologia das plantas representativas dos respectivos biomas e por suas vinculações com o relevo. Gramíneas e plantas lenhosas são vegetais muito distintos, que geralmente se excluem mutuamente. Este verdadeiro antagonismo resulta tanto de diferenças no sistema radicular, como de economia hídrica. ${ }^{35}$

Pelo sistema radicular intensivo, finamente ramificado e distribuído num volume relativamente pequeno de solo, as gramíneas são especialmente adaptadas a regiões secas, motivo pelo qual, ao final do Pleistoceno, predominava amplamente em todo o sul do Brasil uma vegetação campestre, de natureza estépica. O campo nativo, em outras palavras, tem caráter relitual, antecedendo às florestas no Rio Grande do Sul.

As espécies lenhosas, em contraste, possuem sistema radicular extensivo e suas grossas raízes alcançam maiores distâncias, ocupando grande volume de solo, embora com menor densidade. Árvores e arbustos, desse modo, mostram-se especialmente eficientes em solos rochosos, nos quais a água se reparte desigualmente, tanto em zonas tropicais como temperadas.

No avanço holocênico ${ }^{36}$ das florestas sobre os campos, a vegetação silvática logrou maior sucesso nas encostas montanhosas e em outras áreas dissecadas pela rede de drenagem, contrastando com a vegetação campestre, dominante em terrenos mais planos ou de relevo suavemente ondulado. Em poucos locais mostra-se tão claramente a transição abrupta entre campo e floresta como nos arredores de Santa

\footnotetext{
${ }^{35}$ MARCHIORI, J. N. C. Fitogeografia do Rio Grande do Sul: Campos sulinos. Porto Alegre: EST, 2004. p. 13-30.

${ }^{36}$ Referente ao Holoceno ou Recente, os últimos 10.000 anos na escala geológica do tempo.
}

Maria, evidenciando o estreito vínculo entre relevo e tipo de vegetação: florestas, em áreas acidentadas; campos, em terrenos mais planos.

$\mathrm{Na}$ região em foco, a principal mancha florestal é a que reveste as encostas da Serra Geral $^{37}$ ao norte da cidade, havendo na Depressão Central uma nítida dominância de campos nativos, entremeados de matas ciliares e capões ${ }^{38}$.

Sobre esta paisagem natural de campos e florestas, a ação antrópica também produziu importantes modificações ao longo do tempo. Ocorre que a atividade humana sempre gera impactos sobre a natureza, seja de forma direta ou indireta.

Em princípios do século 17, antes da chegada dos primeiros jesuítas, o quadro da vegetação natural no centro do Rio Grande do Sul já sofria as conseqüências da agricultura itinerante praticada pelos índios guarani, particularmente nas florestas da encosta da Serra Geral. Baseada no corte e queima de parcelas de mata, indispensáveis ao estabelecimento de pequenas roças para o cultivo de mandioca, milho, batatadoce, amendoim, feijão, abóbora, urucum, fumo e algodão, a devastação florestal produzida por esses indígenas chamou atenção do Padre Roque González ${ }^{39}$, que registrou serem já escassas as terras para plantio, no distante ano de 1626:

\footnotetext{
${ }^{37}$ Em Santa Maria, o segmento da Serra Geral recebe o nome de serra de São Martinho.

${ }^{38}$ De origem tupi (caá - apoam), essa palavra significa "mata redonda"; no Brasil, o termo "capão" é popularmente atribuído a fragmentos florestais de áreas campestres, não associados à rede de drenagem (mata ciliar) e de contorno mais ou menos arredondado.

${ }^{39} \mathrm{Um}$ dos mais importantes missionários de seu tempo, Roque González de Santa Cruz nasceu em Assunção (Paraguai), no ano de 1576, e foi assassinado pelos índios em Caaró (Rio Grande do Sul), em 15-11-1628. Primeiro jesuíta a adentrar no Tape (atual Rio Grande do Sul), o padre Roque subiu pelo rio Ibicuí em março de 1626; a região central do Estado, entretanto, só foi alcançada pelo missionário em sua segunda visita, realizada em maio do mesmo ano.
} 
“(...) em todo o Tape não se encontra posto para reduzirem sequer 200 famílias, que, como antigamente fosse muita gente, acabaram com os matos e assim plantam entre cerros e penhascos e vivem em aldeolas, cujas maiores são de 100 índios".40

Após cinco ou seis anos de uso, cada família buscava um novo pedaço de mato, deixando em abandono a roça antiga. Em dez ou quinze anos de descanso, com a vegetação recomposta na fase de capoeirão ou de mata secundária, a mesma área encontrava-se novamente em condições de ser reutilizada, graças à fertilização natural produzida pela floresta jovem. Desconhecendo animais domésticos de grande porte e praticando a agricultura em pequenas clareiras, os índios não tiveram influência sensível na origem das áreas campestres gaúchas, apesar do intenso desmatamento produzido. ${ }^{41}$

Cabe salientar que esses repetidos distúrbios na estrutura florestal não produziram efeitos danosos permanentes. Devido à área restrita dos impactos, pulverizados em fragmentos de pequena extensão, o seu efeito na estrutura florestal pode ser comparado à dinâmica da mortalidade e formação natural de clareiras. Além de favorecer a coexistência de espécies pionei$\operatorname{ras}^{42}$ e climácicas ${ }^{43}$, essa agricultura itinerante fornece, inclusive, uma explicação razoável para a sobrevivência e conservação de espécies sabidamente heliófilas na estrutura da Floresta Estacional, como é o caso do pinheiro-brasileiro (Araucaria angustifolia) em certos pontos da Depressão Central gaúcha.
A respeito dos índios minuanos, que habitaram em áreas campestres do município de Santa Maria, acredita-se que sua cultura, menos desenvolvida, deixou impactos de menor monta, por viverem da caça, pesca e coleta de frutos, ressalvando-se, todavia, a queima eventual de parcelas de campo.

A introdução do gado bovino foi a ação ambiental mais impactante do primeiro ciclo jesuítico, encerrado em 1638 na região de Santa Maria, com o êxodo dos índios e padres da redução de São Cosme e São Damião ${ }^{44}$ para a margem direita do rio Uruguai, acossados por bandeirantes. Favorecido pelas abundantes pastagens e aguadas, a proliferação do gado alçado teve grande influência sobre a vegetação nativa, sobretudo de áreas campestres.

No tocante às florestas, o aldeamento e posterior transmigração da população indígena favoreceu a sua recomposição, notadamente na Encosta da Serra Geral, conferindo às mesmas uma exuberância nunca antes alcançada. A espessa mataria, recomposta naturalmente na antiga Serra dos Tapes ${ }^{45}$, explica o nome de "Monte Grande", com que os espanhóis passaram a designar a região. Cabe frisar que o termo "monte" significa mato ou floresta, em espanhol, sendo, portanto, muito adequado para designar o importante maciço florestal que se estende de leste a oeste, no centro do Rio Grande do Sul, em torno do paralelo de $29^{\circ} 30^{\prime}$. Não custa lembrar, neste momento, que Santa Maria guarda esta influência castelhana em seu nome tradicional (da Boca do Monte), assim como a vila de
${ }^{40}$ JAEGER, L. G. Os bem-aventurados Roque González, Afonso Rodríguez e João Del Castillo, mártires do Caaró e Pirapó. Porto Alegre: Selbach, 1951. p. 194.

${ }^{41}$ BRUXEL, A. O gado na antiga Banda Oriental do Uruguai. Pesquisas, São Leopoldo, série História, n. 13, p. 13-14, 1960.

${ }^{42}$ Espécies vegetais típicas da fase inicial da sucessão.

${ }^{43}$ Espécies típicas da fase final de sucessão (clímax florestal).
${ }^{44}$ Fundada pelo padre jesuíta Adriano Formoso (1634), situava-se em terras do atual sítio urbano de Santa Maria, conhecido pelos índios como Ibitimiri (BELTRÃO, R. Cronologia histórica de Santa Maria e do extinto município de São Martinho. Canoas: La Salle, 1979. p. 12).

${ }^{45}$ Denominação atribuída à Serra Geral no centro do Rio Grande do Sul, constante na literatura jesuítica do século XVII. Resta informar que os guarani da região, nesta época, eram chamados de Tapes. 
Boca do Monte ${ }^{46}$, localidade no interior do município.

A partir de 1682, com o retorno de índios e jesuítas para a margem oriental do rio Uruguai ${ }^{47}$, foram fundados os "Sete Povos das Missões" e criadas estâncias para cuidar do gado que proliferara nos campos do Rio Grande. Neste segundo ciclo jesuítico, o atual sítio urbano de Santa Maria integrou a "Invernada de São Luiz" ${ }^{48}$, de acordo com informe do Padre Francisco de Avendano. ${ }^{49}$

Em março de 1756, quando a vanguarda dos exércitos de Gomes Freire ${ }^{50}$ e Andonaegui ${ }^{51}$

${ }^{46} \mathrm{O}$ nome dessa vila tem origem mais antiga e com o mesmo sentido. Ocorre que nas proximidades da atual vila de Boca do Monte ficava o caá-roqué, caá-guaçu-roqué ou caá-yurú dos índios (porteira-do-mato, porteira-domato-grande e boca-da-picada, respectivamente): uma estreita passagem ligando a Depressão Central ao Planalto Médio (São Martinho), através da mataria da Serra Geral.

${ }^{47}$ A redução de São Cosme e Damião não retornou ao Rio Grande do Sul.

48 "Ymbernada de San Luiz, que cae detras de la sierra, en el Tetangue, que fue de los SS. Mart. San Cosme i San Damian. (...) ...esta imviernada es un rincon de Tierra Serrada por todas partes con el Arroio llamado Baca cai miri, i con el monte grande que le cerca por todas partes...". (Informe do Padre Francisco de Avendano (da Redução de São Luis) contra o Padre Antônio Ximenes (da redução de São Miguel), o qual se dizia lesado, no tocante às vacas de sua estância. Cartas anuas, Coleção De Angelis, p. 104).

${ }^{49}$ Sobre este ponto, o historiador Aurélio Porto fornece informação distinta, porém equivocada, ao afirmar que a referida área teria servido como um posto da estância do Povo de São João (PORTO, A. História das Missões Orientais do Uruguai. Porto Alegre: Selbach, 1954. v. 1. p. 331). $\mathrm{O}$ texto de Avendano, transcrito na nota anterior, não deixa, todavia, margem a dúvidas: o sítio urbano de Santa Maria, em verdade, fez parte da invernada de São Luiz, compondo um rincão entre a Serra Geral e o Vacacaí Mirim; entre 1634 e 1638, estas terras pertenceram à redução de São Cosme e São Damião. Resta esclarecer que o Vacacaí Mirim é o atual Arenal, arroio que, com seu afluente Cadena (arroio de Santa Maria, na época), isolava o dito rincão.

${ }^{50}$ Gomes Freire de Andrada (Estremoz, Portugal, 1685 Rio de Janeiro, 1763$), 1^{\circ}$ conde de Bobadela.

${ }^{51}$ Don Joseph de Andonaegui y Plaza (1680-1761), Tenente General, Governador e Capitão-General das Províncias do Rio de La Plata, foi o comandante da tropa espanhola enviada para a entrega dos Sete Povos das Missões aos portugueses (1756). chegou à entrada sul da Picada de São Martinho, o diário do primeiro deles não deixou de registrar a dificuldade oferecida às tropas, na subida da Serra, por um "mato do mais alto e grosso arvoredo". 52 Na mesma oportunidade, Dom Francisco Graell ${ }^{53}$ também assinalou em diário que a mataria transposta era fechada "com árvores muito altas, embora não muito robustas", apesar da presença de "troncos de dois ou três palmos de largura". ${ }^{44}$ Ocorre que, passados 122 anos da fundação de São Cosme e Damião e quase outro tanto da fuga dos índios para a margem ocidental do rio Uruguai, a floresta estacional da encosta, esvaziada dos antigos habitantes, pôde alcançar seu pleno desenvolvimento, compondo uma estrutura luxuriante, à semelhança de áreas bem conservadas do atual Parque Estadual do Turvo, no extremo noroeste do Estado. Essa realidade manteve-se inalterada até depois de 1797, marco inicial do povoamento no "Rincão de Santa Maria", decorrente do acampamento da "Partida Portuguesa da $2^{\text {a }}$ Subdivisão da Comissão Demarcadora de Limites", na coxilha correspondente ao atual centro da cidade.

Quando o brigadeiro Sebastião Xavier da Veiga Cabral da Câmara ${ }^{55}$ determinou a paralisação definitiva dos trabalhos da Comissão Demarcadora (1801), o pequeno povoado logrou vingar ao esvaziamento pelo afluxo de novos moradores e de empregados civis da extinta Partida, que decidiram radicar-se no "Acampamento de Santa Maria”. Os primeiros viajantesnaturalistas chegados à região ainda encontra-

${ }^{52}$ BELTRÃO, R., 1979. Op. cit., p. 14.

${ }^{53}$ Capitão de Dragões e oficial representante da Coroa Espanhola na expedição contra os Sete Povos Missioneiros (1755-1756).

${ }^{54}$ GRAELL, F. Passado missioneiro no diário de um oficial espanhol. Santa Cruz do Sul: EDUNISC, 1998. p. 69.

${ }^{55}$ Natural da freguezia de Santa Maria de Soutello (Portugal, 1742), faleceu na vila do Rio Grande a 5/11/1801, aos 59 anos de idade. Primeiro Comissário na demarcação de limites decorrentes do Tratado de Santo Ildefonso, ele acumulou as funções de governador do Rio Grande de São Pedro, até sua morte. 
ram uma natureza praticamente intacta - tanto a florestal como a campestre -, devido à modesta pressão exercida por uma população escassa e de reduzida atividade econômica.

No século XIX, o crescimento de Santa Maria e, por conseguinte, a pressão sobre seus recursos naturais só foi alterada, substancialmente, com a chegada dos primeiros colonos italianos à região (1877). Assentados em terras florestais devolutas, a colonização implicou, necessariamente, em devastação de grande magnitude, sobretudo nas encostas da Serra Geral.

A chegada da ferrovia, em outubro de 1885 , trouxe novo e vigoroso impulso ao desenvolvimento regional. Para as florestas nativas, esse progresso implicava em devastação, posto que, à época, ainda não existia a prática da silvicultura em nosso meio. Madeira para dormentes e lenha para alimentar caldeiras de locomotivas, passaram a exigir uma derrubada crescente de árvores, levando à exploração irracional desses recursos. Proliferaram, então, as clareiras nos morros que cercam a cidade, reconhecidas em antigas fotos, num processo que perdurou muitas décadas, com sérios prejuízos ambientais. Os baixos valores fitossociológicos atualmente observados, no tocante a espécies madeireiras nobres, bem como a expressiva variação florística entre diferentes parcelas da moderna floresta estacional de encosta, constituem testemunhos dessa exploração sistemática, que vigorou até além da metade do século vinte.

$\mathrm{Na}$ zona campestre, as matas ciliares e capões também sofreram redução de área, sobretudo após a introdução do cultivo de arroz irrigado. A predação e o pisoteio de regenerações pelo gado doméstico também influíram na diversidade e conservação da estrutura florestal. No tocante ao campo nativo propriamente dito, a influência antrópica não deixou seqüelas menores em sua estrutura e composição florística.

O êxodo rural, notadamente na pequena propriedade, somado à preocupação crescente com as questões ambientais e a um maior rigor no cumprimento da legislação pertinente, favoreceram a recomposição da floresta nativa nas últimas décadas, num processo claramente perceptível, sobretudo nas montanhas que cercam a cidade.

Feitas estas breves considerações acerca da dinâmica natural da vegetação e sobre os efeitos da atividade humana ao longo do tempo, podese dar início, na seqüência, à análise das florestas e campos naturais no município de Santa Maria.

\section{A FLORESTA DA ENCOSTA DA SERRA GERAL}

A floresta que se encontra ao norte da cidade de Santa Maria é parte de uma grande mancha que reveste a encosta da Serra Geral, no centro do Rio Grande do Sul. Desenvolvida em torno do paralelo de $29^{\circ} 30^{\prime}$, essa faixa florestal estende-se, com largura variável, desde as proximidades de Osório, onde estabelece contato com a Floresta Atlântica propriamente dita, até seu limite ocidental, entre Manoel Viana e Unistalda. Com poucos quilômetros de largura na região de Santa Maria, ela restringe-se ao talude dissecado do Planalto Médio, cedendo prontamente lugar a campos, tanto ao pé da Serra, no sítio urbano, como nas coxilhas dos municípios de Itaara e São Martinho.

De caráter estacional ${ }^{56}$, essa floresta é marcada fisionomicamente pela acentuada ca-

${ }^{56}$ Essa unidade foi definida como "Floresta Estacional Decidual", pelo RADAMBRASIL (VELOSO, H. P., GÓES-FILHO, L. Fitogeografia brasileira: Classificação fisionômico-ecológica da vegetação neotropical. Boletim Técnico. Projeto RADAMBRASIL. Ser. Vegetação, Salvador, v. 1, p. 1-80, 1982), e como "Região da Floresta Estacional Decídua”, por Pedro Furtado Leite (LEITE, P. F. As diferentes unidades fitoecológicas da região sul do Brasil - Proposta de classificação. Cadernos de Geociências, Rio de Janeiro, n. 15, p. 1-191, 1995). Entre outras, constam para a mesma tipologia as seguintes denominações: "Floresta Latifoliada da Fralda da Serra Geral” (REITZ, R, KLEIN, R. M., REIS, A. Projeto Madeira do Rio Grande do Sul. Sellowia, Itajaí, n. 3435 , p. 1-525, 1983); "Floresta Latifoliada Tropical" 
ducidade do estrato superior. Sob o ponto de vista florístico, ela compõe-se principalmente de Leguminosas (Fabaceae), como a grápia (Apuleia leiocarpa), o angico (Parapitadenia rigida), a cabriúva (Myrocarpus frondosus), a timbaúva (Enterolobium contortisiliquum), os angicos-brancos (Albizia edwallii, A. niopoides), a corticeira-do-mato (Erythrina falcata), a canela-do-brejo (Machaerium stipitatum), a farinha-seca (Lonchocarpus nitidus), o pau-canzil (Lonchocarpus campestris). São também decíduas ou semidecíduas: a cangerana (Cabralea canjerana), o cedro (Cedrela fissilis), o açoita-cavalo (Luehea divaricata), a guajuvira (Cordia americana), a caroba (Jacaranda micrantha), o ipê-roxo (Tabebuia heptaphylla), o louro (Cordia trichotoma), o umbu (Phytolacca dioica), o pessegueiro-do-mato (Prunus myrtifolia), a tajuva (Maclura tinctoria), a guavirova (Campomanesia xanthocarpa), o marmeleiro (Ruprechtia laxiflora), o tarumã (Vitex megapotamica), a paineira (Ceiba speciosa), os camboatás (Cupania vernalis, Matayba elaeagnoides) e a cerejeira (Eugenia involucrata). Dentre as perenifólias, menos importantes no dossel, citam-se: a batinga (Eugenia rostrifolia), a murta (Blepharocalyx salicifolius), o guapuriti (Plinia rivularis), a caixeta (Schefflera morototonii), as figueiras (Ficus adathodifolia, F. luschnathiana), o gerivá (Syagrus romanzoffiana) e a maria-preta (Diospyros inconstans).

No estrato médio, predominam a canelaguaicá (Ocotea puberula), a canela-amarela (Nectandra lanceolata), a canela-louro (Nectandra megapotamica), a canela-verme-

(ROMARIZ, D. de A. Aspectos da vegetação do Brasil. São Paulo: edição da autora, 1996. 60 f.); e "Distrito das Selvas", integrante da "Província Paranense" e "Domínio Amazônico" (CABRERA, A. L., WILLINK, A. Biogeografia de América Latina. Washington: Secretaria General de la Organización de los Estados Americanos, 1973. 350 p.). lha (Aiouea saligna), a canela-ferrugem (Ocotea silvestris) e a canela-lageana (Ocotea pulchella), além de indivíduos jovens das espécies típicas do dossel.

$\mathrm{O}$ estrato das arvoretas, bastante homogêneo, compreende a laranjeira-do-mato (Gymnanthes concolor), o cincho (Sorocea bonplandii), três espécies de catiguás (Trichilia catigua, T. claussenii, T. elegans), o carvalhinho (Casearia silvestris), o catiguá-morcego (Guarea macrophylla) e a primavera (Brunfelsia australis). Dentre os arbustos, salientam-se Rubiáceas do gênero Psychotria, o urtigão do mato (Urera baccifera) e a embira (Daphnopsis racemosa).

$\mathrm{Na}$ sinúsia das lianas e escandentes, destacam-se algumas Bignoniáceas, dos gêneros Clytostoma, Cuspidaria, Macfadyena e Pithecoctenium, Sapindáceas (Serjania laruotteana, Serjania meridionalis, Thinouia mucronata, Urvillea uniloba), Leguminosas (Bauhinia microstachya), Aristoloquiáceas (Aristolochia triangularis), Ramnáceas (Gouania ulmifolia) e Amarantáceas (Chamissoa altissima).

Relativamente escassas e pouco conspícuas na estrutura da vegetação, comparado às florestas Atlântica ${ }^{57}$ e com Araucária ${ }^{58}$, as epífitas compreendem, mesmo assim, diversas Pteridófitas, Orquídeas, Cactáceas, Piperáceas e Bromeliáceas.

A orla da floresta é marcada por um emaranhado de arvoretas, arbustos e plantas escandentes, destacando-se o carvalhinho (Casearia silvestris), a pitangueira (Eugenia uniflora), o limoeiro-do-mato (Randia ferox), o veludinho (Guettarda uruguensis), a viuvinha (Chomelia obtusa), o esporão-de-galo (Strychnos brasiliensis), as unhas-de-gato (Acacia tucumanensis, Acacia velutina), o

\footnotetext{
${ }^{57}$ Floresta Ombrófila Densa, segundo Veloso \& Góes Filho (1982).

${ }^{58}$ Floresta Ombrófila Mista, segundo Veloso \& Góes Filho (1982).
} 
rabo-de-bugio (Dalbergia frutescens) e a taleira (Celtis spinosa).

$\mathrm{Na}$ vegetação de capoeira, predominam a crindiúva (Trema micrantha), o fumo-bravo (Solanum mauritianum), a caroba-amarela (Tecoma stans) e o urtigão-manso (Boehmeria caudata).

No topo de morros, em sítios pedregosos ou de solos rasos, a canela-de-veado (Helietta apiculata) torna-se dominante, imprimindo-se na fisionomia da vegetação por sua folhagem rala, verde-clara. Das acompanhantes, salientam-se: o ipê-roxo (Tabebuia heptaphylla), o guabiju (Myrcianthes pungens), o bugreiro (Lithraea molleoides), a tuna (Cereus hildmannianus) e a Schaefferia argentinensis, arvoreta de vinculação chaquenha. Embora raros, nestes sítios podem ser encontrados até mesmo o carandá (Tritrinax brasiliensis), como na região de Santo Antão, e a criúva (Agarista eucalyptoides). Mais freqüentes na Serra do Sudeste, estas três últimas espécies constituem verdadeiros relictos na Serra Geral, devendo ser interpretadas como sobreviventes da invasão holocênica de elementos tropicais que deu origem à moderna Floresta Estacional, após o término da última glaciação.

Junto aos cursos d'água, encontram-se as mesmas espécies reófilas a serem descritas para as matas ciliares de áreas campestres, destacando-se, todavia, a presença (rara, em verdade) da Colliguaya brasiliensis, elemento andino de ocorrência eventual em riachos que descem a Serra Geral, no centro do Estado.

Sob o ponto de vista fitogeográfico, a Floresta Estacional de Santa Maria vincula-se, estreitamente, à Floresta do Alto Uruguai ${ }^{59}$, diferindo, contudo, pela ausência de algumas espécies importantes, como a maria-preta (Diatenopteryx sorbifolia), a canafístula (Peltophorum dubium), a jaboticaba (Plinia trunciflora), a tuvarana (Cordyline spectabilis) e o sangue-

\footnotetext{
${ }^{59}$ Ambas as unidades foram classificadas no Radambrasil como Floresta Estacional Decidual (Veloso \& Góes Filho, 1982).
}

de-dragão (Croton urucurana). Estudos recentes têm reduzido gradativamente essa lista, pois o assucará (Gleditschia amorphoides) e o alecrim (Holocalyx balansae) ${ }^{60}$ são ainda comuns nos municípios de Jaguari e Mata, o guatambu (Balfourodendron riedelianum) não é raro em Nova Palma e Vale Vêneto, localidades próximas a Santa Maria, e o jasmim-grado (Rauvolfia sellowii) foi recentemente encontrado em inventário florestal na região da Quarta Colônia. ${ }^{61}$ A presença de elementos representativos da Floresta Atlântica propriamente dita, ao contrário, é notavelmente reduzida em Santa Maria, salientando-se o mata-olho-da-serra (Pachystroma longifolium) e a figueira-do-litoral (Ficus citrifolia) ${ }^{62}$

Explorada desde o estabelecimento dos primeiros moradores no atual sítio urbano de Santa Maria, a Floresta Estacional não esconde os efeitos dessa retirada sistemática de lenha e madeiras nobres, pelo menos a olhos mais treinados. Seu escasso valor econômico na atualidade, conseqüência da exploração seletiva das espécies mais valiosas ao longo do tempo, associado a grande número de árvores por hectare (e árvores de diâmetros pequenos), são atributos típicos do estágio secundário de sucessão, contrastando com a luxuriante floresta primária encontrada pelos integrantes da Comissão Demarcadora de Limites, responsáveis pelo povoamento do "Rincão de Santa Maria" ao final do sécu-

${ }^{60}$ A presença do alecrim foi também comprovada no município de Formigueiro, em plena Depressão Central (SCHMIDT, M. V. C., MARCHIORI, J. N. C., NASCIMENTO, A. R. T., ALVAREZ FILHO, A. Relações histórico-florísticas, fitossociologia e aspectos ecológicos do alecrim (Holocalyx balansae Mich.) em floresta primária, na região de Formigueiro. Ciência e Natura, Santa Maria, n. 15, p. 161-183, 1993).

${ }^{61}$ BRENA, D. A., LONGHI, S. J. Inventário Florestal. In: ITAQUI, J. (Org.). Quarta Colônia: Inventários Técnicos. Santa Maria: Condesus, Quarta Colônia, 2002.256 p.

${ }^{62}$ Esta espécie aparece freqüentemente na literatura como Ficus organensis Miquel, binômio atualmente reduzido à sinonímia. 
lo XVIII. ${ }^{63}$ Outra conseqüência inequívoca da ação antrópica é a incorporação na estrutura florestal de espécies exóticas, como a uva-doJapão (Hovenia dulcis), a ameixeira (Eriobotrya japonica), a amoreira (Morus nigra) e alguns citrus (Citrus reticulata, Citrus sinensis).

Em área contígua à Floresta Estacional, no topo do Planalto Médio e igualmente em contato com os campos dessa região fisiográfica, encontram-se fragmentos de uma unidade distinta: a Floresta Ombrófila Mista. O texto de Robert Avé-Lallemant, transcrito anteriormente, informa-nos sobre sua existência em terras do atual município de Itaara, bem como o antigo nome da localidade e o de uma estação ferroviária vizinha (Pinhal). Situado fora dos atuais limites do município de Santa Maria, mesmo assim convém, em breve comentário, trazer algumas informações acerca dessa unidade fitogeográfica, até mesmo porque alguns de seus elementos representativos podem ser eventualmente encontrados no interior da Floresta Estacional.

O traço distintivo da Floresta Ombrófila Mista, como indicado no próprio nome, é a mistura de coníferas e folhosas em sua composição florística, além da reunião de um importante contigente extratropical aos elementos típicos da Floresta Estacional, salientando-se, entre os primeiros, o pinheiro-brasileiro (Araucaria angustifolia), o pinheiro-bravo (Podocarpus lambertii), o pau-sabão (Quillaja brasiliensis), o carvalho-brasileiro (Roupala brasiliensis), a caúna (Ilex brevicuspis), a congonha (Ilex dumosa) e os canudos-de-pito (Escallonia bifida, Escallonia megapotamica).

${ }^{63} \mathrm{O}$ início do povoamento coincide com o acampamento da "Partida Portuguesa da $2^{\mathrm{a}}$ Subdivisão da Comissão Demarcadora de Limites" no "Rincão de Santa Maria", ocorrido entre fins de julho de $1797 \mathrm{e}$ a primeira metade de 1798. O sítio escolhido, dorso da coxilha correspondente ao atual centro urbano de Santa Maria, ficava em terreno da estância do Pe. Ambrósio José de Freitas (Beltrão, R. Cronologia histórica de Santa Maria e do extinto município de São Martinho. Canoas: La Salle, 1979. p. 29-30).

\section{MATAS CILIARES}

Localizado no centro do Estado, o município de Santa Maria participa de duas bacias hidrográficas divergentes - a do Ibicuí, afluente do Uruguai, e a do Vacacaí, que encaminha suas águas para o lago Guaíba -, distando o divisor de ambas, na forma de modestas coxilhas, cerca de 15 quilômetros a oeste da cidade. Nessas terras baixas da Depressão Central, a vegetação dominante, de campos nativos, era originalmente interrompida apenas por matas ciliares $\mathrm{e}$ capões.

Matas (ou florestas) ciliares, por vezes ditas "de galeria", "ripárias" ou "ripícolas", são formações silváticas associadas à margem de rios e outros cursos d'água. Como "pontas de lança" ${ }^{64}$ no avanço da floresta sobre os campos, as matas ciliares limitam-se a um estreito cordão ou compõem faixas de largura variável, segundo as características do relevo, compreendendo uma ou mais comunidades ao longo do transecto, distintas entre si pela composição florística associada aos respectivos hábitats.

Junto aos cursos d'água, adaptadas para suportar a força da correnteza e eventual submersão durante as enchentes, as reófitas ${ }^{65}$ compõem uma comunidade singular de arbustos e árvores pequenas, geralmente conhecidas pelos nomes de sarandi ${ }^{66}$ ou amarilho: Sebastiania

${ }^{64}$ De admirável efeito, essa expressão foi cunhada por Balduíno Rambo, importante fitogeógrafo sul-riograndense.

${ }^{65}$ Planta adaptada para crescer em água corrente (ART, H. W. Dicionário de ecologia e ciência ambiental. São Paulo: Companhia Melhoramentos, 1998. p. 460).

${ }^{66} \mathrm{De}$ origem tupi (çarã-ty), o termo aplica-se a diversas espécies de Euforbiáceas, Sapotáceas, Combretáceas e Leguminosas (Fabaceae), que crescem nas margens de rios e arroios (FURTADO, N. F. Vocábulos indígenas na geografia do Rio Grande do Sul. Porto Alegre: Pontifícia Universidade Católica, 1969. p. 155-156; CUNHA, A. G. da. Dicionário histórico das palavras portuguesas de origem tupi. São Paulo: Melhoramentos/EDUSP, 1989. p. 260; DOCCA, S. Vocábulos indígenas na geographia riograndense. Revista do Instituto Histórico e Geográfico do Rio Grande do Sul, Porto Alegre, I e II trimestre, p. 88-89, 1925). 


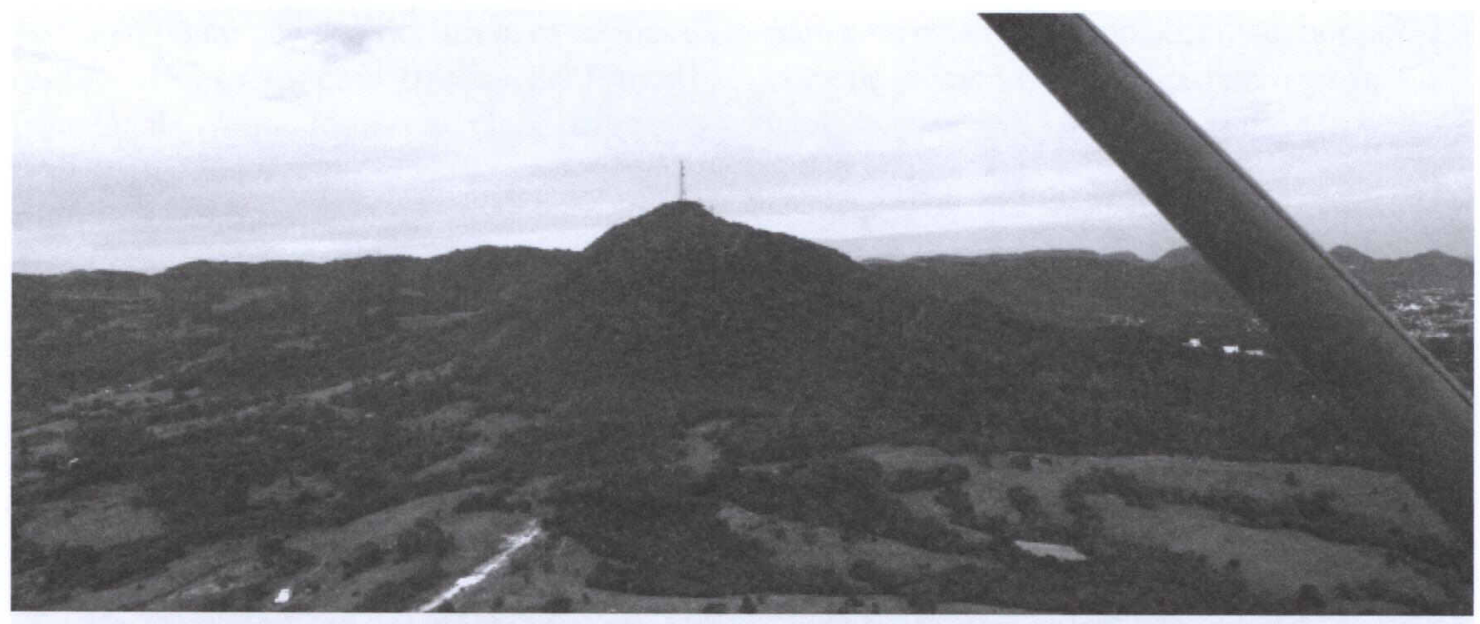

FIGURA 3 - Vista parcial dos morros ao norte da cidade, com fragmentos de Floresta Estacional.

schottiana (amarilho-branco ou branquilho), Terminalia australis (amarilho ou sarandi-amarelo), Cephalanthus glabratus (sarandi-branco ou sarandi-mole), Phyllanthus sellowianus (sarandi ou sarandi-vermelho) e Pouteria salicifolia (sarandi-mata-olho). A lista tende a completar-se quando se incluem os angiquinhos ou quebra-foices (Calliandra brevipes, Calliandra tweediei) e o salso-crioulo (Salix humboldtiana). Providas de denso sistema radicular, todas estas espécies são de pequeno porte, com exceção da última, possuindo troncos delgados e flexíveis, morfologicamente adaptados à reofilia. A respeito do salso-crioulo, cujos troncos podem atingir dimensões consideráveis, a presença nessa comunidade justifica-se pelo robusto e denso sistema radicular, bem como pela abundância de fibras gelatinosas no lenho, responsável pela notável flexibilidade de seu tronco e ramos.

No alto de barrancos, em situação ecologicamente menos restritiva, predominam os ingazeiros (Inga vera, Inga semialata), o branquilho (Sebastiania commersoniana), o branquilho-leiteiro (Sebastiania brasiliensis) e o taquaruçu (Guadua trinii).

Nos sítios em que a topografia favoreceu o avanço da floresta pela várzea adjacente, a ve- getação assume um caráter aluvial, podendo incluir representantes típicos da Floresta Estacional da Encosta da Serra Geral, salientando-se, entre outros: o açoita-cavalo (Luehea divaricata), o angico (Parapiptadenia rigida), o marmeleiro (Ruprecthia laxiflora), os ariticuns (Rollinia rugulosa, Rollinia salicifolia), a canela-dobrejo (Machaerium stipitatum) e diversas mirtáceas (Campomanesia xanthocarpa, Eugenia uniflora, Eugenia mansoi, Eugenia uruguayensis, Gomidesia palustris).

$\mathrm{Na}$ orla da mata ciliar predominam arvoretas e arbustos, como a unha-de-gato (Acacia tucumanensis), o veludinho (Guettarda uruguensis), a viuvinha (Chomelia obtusa), a pata-de-vaca (Bauhinia forficata) e as "acácias" de flores vermelhas ou amarelas (Sesbania punicea, Sesbania virgata). Por vezes, a orla da mata é dominada pelo gravatá (Bromelia antiacantha), compondo um halo no contato com o campo, ou pelo maricá (Mimosa bimucronata), que tende a formar populações homogêneas.

Em várzeas paludosas da Depressão Central, como em muitos trechos da margem dos rios Ibicuí-Mirim, Arenal e Vacacaí, a corticeirado banhado (Erythrina cristagalli) chega a tor- 


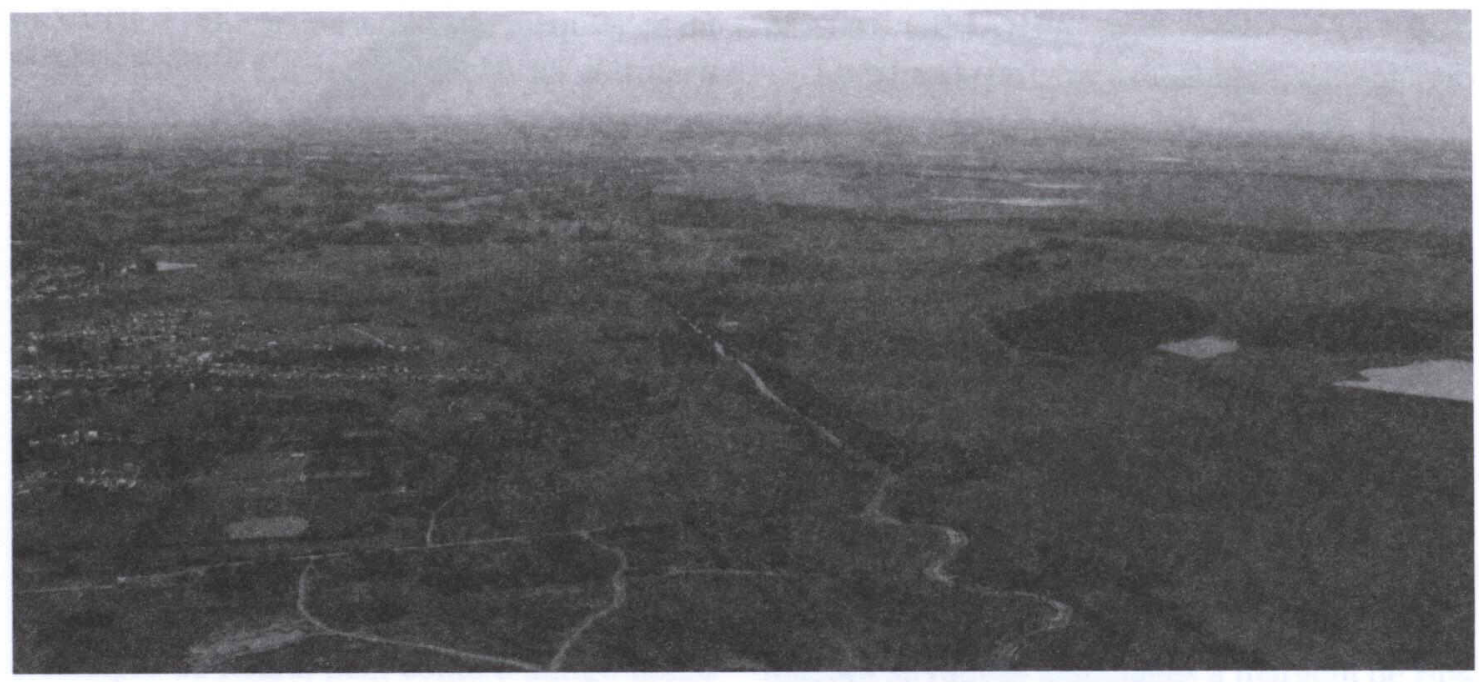

FIGURA 4 - Paisagem típica da Depressão Central, tomada a sudoeste da cidade, destacando a predominância de campos nativos, com mata ciliar junto ao Arroio Cadena e capões-de-mato.

nar-se dominante, compondo uma vegetação pauciespecífica, conhecida popularmente como seival $^{67}$.

\section{CAPÕES}

De origem indígena ${ }^{68}$, a palavra "capão" aplica-se, regionalmente, às ilhas de vegetação silvática dispersas em áreas campestres. Cabe salientar que o termo é de utilização bastante antiga na literatura sul-rio-grandense, constando sua definição no famoso "Diário Resumido e Histórico", de Sebastião Xavier da Veiga Cabral da Câmara ${ }^{69}$ e José de Saldanha ${ }^{70}$, firmado no

\footnotetext{
${ }^{67}$ Mata de ceibos, outro nome popular atribuído à mesma espécie; ceibal, em espanhol.

68 "Todo o seu aspecto externo difere grandemente dos outros tipos de floresta, razão por que os tupinambás lhe atribuíram o nome que melhor destaca as suas principais características: estes índios a chamam de "caaapoam", isto é, mata convexa ou circular, que os portugueses registraram com a corruptela "capão" [de mato]". (MARTIUS, C. F. Von. A viagem de Von Martius. Flora Brasiliensis. Rio de Janeiro: Editora Index, 1996. p. 26).

${ }^{69}$ Ver nota 55 (p. 12).

${ }^{70}$ Geógrafo e astrônomo da " $1{ }^{\mathrm{a}}$ Divisão da Demarcação d'América Meridional”' (Lisboa, c. 1758; Porto Alegre, 28/5/1808).
}

"Acampamento geral do Monte Grande" (1011-1787), arredores de Santa Maria ${ }^{71}$ : "Palavra uzada pelos Portugueses neste Paiz, e com a qual explicão os pequenos Bosques ou ajuntamento de arvoredos" ${ }^{\prime 2}$. Em outro ponto do mesmo documento, os capões são definidos como "bosques de pouca extensão e separados" 73 , agregando, os mesmos autores, que "aos grande Capões de mato, como nas costas dos rios, lagoas ou pantanais, lhe chamão restingas" ${ }^{74}$.

Localizados em encostas de coxilhas e geralmente associados a fontes d'água ou a locais melhor favorecidos por umidade, os capões apresentam estrutura semelhante à da Floresta Estacional anteriormente considerada.

${ }^{71}$ O "Diário Resumido e Histórico" inclui um dos mais antigos relatos sobre a área do atual sítio urbano de Santa Maria e arredores.

${ }^{72}$ CÂMARA, S. X. da V. C. da, SALDANHA, J. de. Diário resumido e histórico. $1^{\mathrm{a}}$ Divisão da demarcação d'América Meridional. Anais da Biblioteca Nacional, Rio de Janeiro, v. 51, p. 206, 1938.

${ }^{73}$ CÂMARA, S. X. da V. C. da, SALDANHA, J. de, 1938. Op. cit., p. 194.

${ }^{74}$ CÂMARA, S. X. da V. C. da, SALDANHA, J. de, 1938. Op. cit., p. 206. 
Sob o ponto de vista florístico, os capões da região aliam espécies típicas da Floresta Estacional a elementos chaquenhos, como o espinheiro (Sideroxylum obtusifolium), o molho (Schinus polygamus) e a falsa-coronilha (Schaefferia argentinensis).

Dentre os elementos comuns à floresta estacional, predominam: a pitangueira (Eugenia uniflora), a mamica-de-cadela (Zanthoxylum rhoifolium), o coentrilho (Zanthoxylum fagara), o chal-chal (Allophylus edulis), o angico (Parapiptadenia rigida), a guavirova (Campomanesia xanthocarpa), a carne-devaca (Styrax leprosus), o camboatá-vermelho (Cupania vernalis), o guabiju (Myrcianthes pungens), o jasmim-catavento (Peschiera australis), a canela-amarela (Nectandra lanceolata), a canela-lageana (Ocotea pulchela), o marmeleiro (Ruprechtia laxiflora), a guajuvira (Cordia americana) e o gerivá (Syagrus romanzoffiana). Na estrutura dos capões, são igualmente frequientes as figueiras (Ficus adathodifolia, Ficus lushnathiana), a coronilha (Scutia buxifolia) e a cancorosa (Maytenus ilicifolia).

Pelo pisoteio e predação de regenerações, o gado acarreta severos danos à estrutura do capão, reconhecidos pela redução do estrato de arvoretas e arbustos, e o conseqüente favorecimento de ervas típicas do interior da floresta, salientando-se gramíneas dos gêneros Ichnanthus, Oplismenus e Pharus, que chegam, por vezes, a compor um denso estrato herbáceo.

A orla dos capões reúne, basicamente, as mesmas espécies referidas para a situação equivalente na mata ciliar; marcada por arbustos e arvoretas, salientam-se, neste caso: o veludinho (Guettarda uruguensis), a viuvinha (Chomelia obtusa), a pitangueira (Eugenia uniflora), o carvalhinho (Casearia silvestris), a unha-de-gato (Acacia tucumanensis) e o esporão-de-galo (Celtis spinosa). Em outros locais, a orla da mata é dominada pelo gravatá (Bromelia antiacantha), compondo um halo na transição para com o campo limpo ou, então, por populações de maricá (Mimosa bimucronata).

\section{CAMPOS NATIVOS}

Situado quase que inteiramente na Depressão Central, o município de Santa Maria era revestido principalmente de campos nativos, vegetação amplamente dominante nessa região fisiográfica, marcada por extensas planícies aluviais e coxilhas sedimentares.

Em primeiro lugar, há que se ressaltar a grande modificação ocorrida na vegetação campestre no tocante à fisionomia e composição florística, em decorrência da criação de gado, da introdução de espécies exóticas e da utilização da terra para cultivos agrícolas. Mesmo assim, um traço marcante pode ser destacado, de início, para caracterizar a tipologia em questão: o seu caráter intermediário entre os "campos grossos", dominantes no Planalto Médio, e os ditos "finos", da fronteira uruguaio-argentina.

Baseados, principalmente, em espécies herbáceas e arbustivas de hábito cespitoso, a fisionomia da diversificada flora campestre regional alia numerosas gramíneas, notadamente andropogôneas e aristídeas, a um variado contingente de Asteráceas e Apiáceas, entre outras famílias botânicas, salientando-se, ainda, em alguns sítios, a presença conspícua de Mirtáceas anãs.

Em locais úmidos, o capim-caninha (Andropogon lateralis) mostra-se dominante, posição ocupada pelas barbas-de-bode (Aristida jubata e A. laevis) nos mais secos. Dentre as gramíneas cespitosas, salientam-se, ainda, os capins rabo-de-burro (Schizachyrium microstachyum, S. condensatus), o capim ponta-delança (Trachypogon montufari) e a macegaestaladeira (Erianthus trinii). Na mesma posição sociológica, encontram-se muitas Asteraceae, sobretudo dos gêneros Baccharis ${ }^{75}$

${ }^{75}$ BELTRÃO (1962) relaciona 30 espécies do gênero Baccharis, em sua "Flora fanerogâmica de Santa Maria" (Op. cit., p. 17-18). 
(B. trimera, B. megapotamica), Vernonia ${ }^{76}$ (V. nudiflora, principalmente) e Eupatorium ${ }^{77}$. Com suas rosetas basais de folhas e vistosas inflorescências, os "caraguatás" (família Apiaceae) chegam, por vezes, a impor-se na fisionomia dos campos, incluindo diversas espécies na região (Eryngium bracteatum, E. chamissonis, E. ciliatum, E. eburneum, E. elegans, E. horridum, E. sanguisorba). Protegidas no meio das touceiras, encontram-se gramíneas mesotérmicas dos gêneros Briza ( $B$. stricta, B. subaristata), Bromus (B. uruguayensis), Piptochaetium (P. lasianthum) e Stipa (S. sellowiana).

No estrato inferior, a grama-forquilha (Paspalum notatum) domina em terrenos mais secos, juntamente com Paspalum plicatulum, $P$. paucifolium e Piptochaetium montevidense; nos mais úmidos, salientam-se Axonopus affinis e Paspalum pumilum. Em solos muito úmidos, como em banhados, dominam Ciperáreas dos gêneros Cyperus, Eleocharis, Fimbristylis e Rhynchospora, ao lado de gramíneas, como Paspalum ionantum e o capim-santa-fé (Paspalum prionitis).

Em áreas de solos arenosos, sobretudo em sítios próximos à encosta da Serra Geral, a vegetação campestre assume um caráter savânico, marcado pela presença de diversas mirtáceas anãs, salientando-se a guavirova do-campo (Campomanesia aurea) e a goiabeira-do-campo (Acca sellowiana), entre outras.

\section{VEGETAÇÃO E SÍTIO URBANO}

Em capítulo anterior, viu-se que o povoamento de Santa Maria resultou de um acampamento $^{78}$ estabelecido na área correspondente ao atu-

${ }^{76}$ BELTRÃO (1962), cita 20 espécies de Vernonia para Santa Maria (Op. cit., p. 25-26).

${ }^{77}$ BELTRÃO (1962) inclui 31 espécies de Eupatorium, em sua flora de Santa Maria (Op. cit., p. 20-21).

${ }^{78}$ Em junho de 1797, tendo a Divisão Demarcadora recebido ordem de deixar as Missões e buscar proteção junto à guarda portuguesa mais próxima, o pessoal da Partida, sob o comando do Capitão Joaquim Félix da Fonseca, al centro da cidade, provavelmente no segundo semestre de 1797. Em 1801, apesar da paralisação definitiva dos trabalhos da Comissão Demarcadora de Limites, o jovem povoado conseguiu vingar, graças ao aporte de moradores das redondezas e de empregados civis da extinta Partida, decididos a radicar-se no "Acampamento de Santa Maria”. O núcleo da moderna cidade e seus principais eixos viários já estavam definidos nessa época: a antiga rua de São Paulo (atual Acampamento), seguindo o dorso norte-sul da coxilha; o largo fronteiro ao pequeno oratório $^{79}$, origem da atual praça Saldanha Marinho; e a rua Pacífica, atual Dr. Bozano, que segue pela pendente, em direção oeste.

Dez anos antes (1787), o capitão de engenheiros e astrônomo Dr. José de Saldanha ${ }^{80}$ acampara próximo ao "Rincão de Santa Maria", mais precisamente à margem ocidental do arroio de mesmo nome, no chamado "Passo da Areia". ${ }^{81}$

A respeito do "Rincão de Santa Maria" e seu potreiro, o próprio "Diário Resumido e Histórico" esclarece, definitivamente, acerca de seus limites:

\begin{abstract}
"Ao Oeste pelo arroio de Santa Maria de que tomou o nome; ao Sul com o Arenal ou Bacacahy-mirim; ao Norte, pelo mato da Serra e pontas do rio Araricá; ao Leste, pela grande restinga de bosques que, principiando desde o Bacacahy-mirim pouco acima do seu passo chamado do Arenal, e, atravessando na direção do Norte a Coxilha da Forqueta Grande, no lugar das Tronqueiras, vai terminar no Araricá".
\end{abstract}

regressou do Povo de São João Batista, acampando em terreno da estância do Padre Ambrósio José de Freitas. Marco inicial do povoamento, o local escolhido corresponde ao atual centro da cidade de Santa Maria.

${ }^{79}$ A capela primitiva foi construída no mesmo local onde hoje se encontra encontra a herma do Coronel João Niederauer Sobrinho, no canteiro central da avenida Rio Branco, com a frente voltada para o sul (atual praça Saldanha Marinho).

${ }^{80}$ Foi por ocasião dos trabalhos da $1^{\text {a }}$ Comissão Demarcadora de Limites da América Meridional.

${ }^{81}$ Passo do arroio de Santa Maria, o atual Cadena. Atualmente incorporado à área urbana, o Passo da Areia fica a oeste do centro da cidade. 


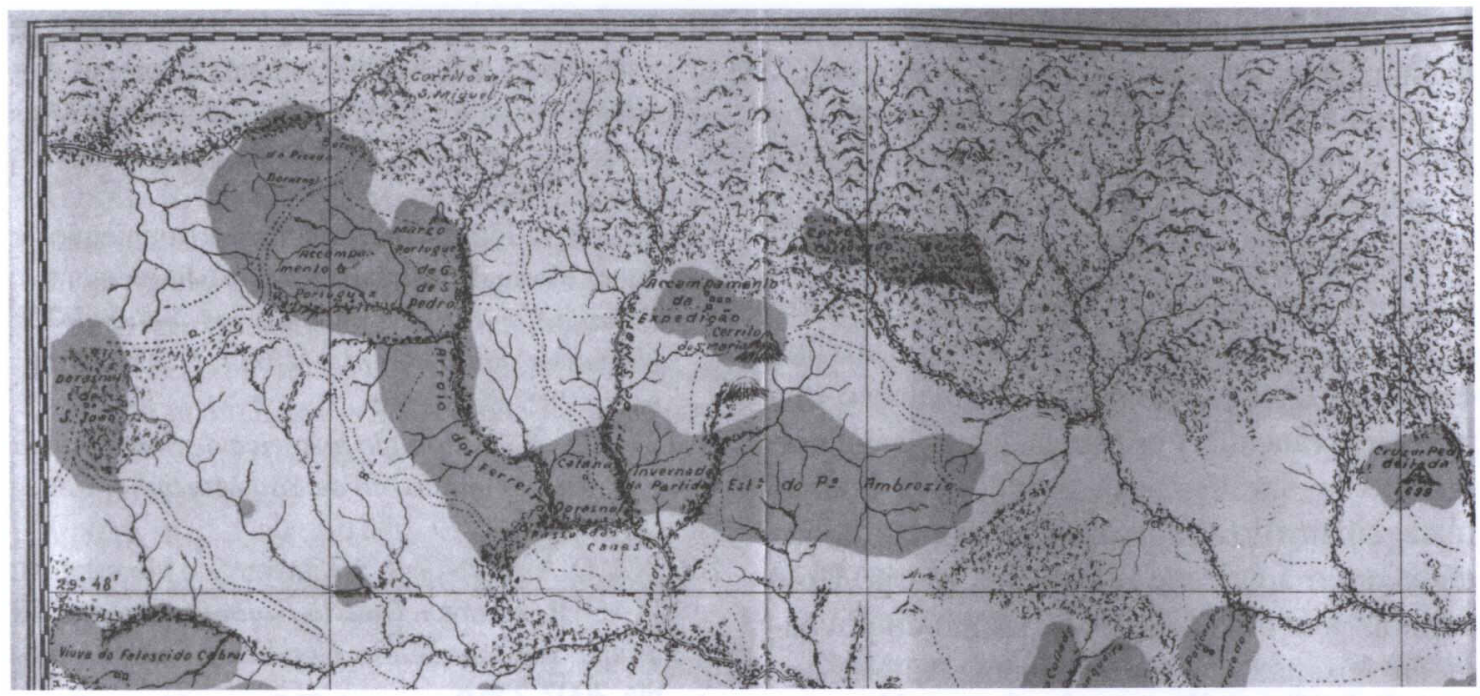

FIGURA 5 - Fragmento do mapa de Francisco Chagas Santos (ano de 1800), posicionando o "Acampamento Portuguez", nas proximidades da atual vila de Boca do Monte, e o "Acampamento da Expedição", no interior do Rincão de Santa Maria, em área correspondente ao atual núcleo central da cidade. (De: João Belém, 1933).

Cabe informar que alguns dos termos geográficos acima utilizados mudaram de nome com o passar do tempo: o arroio de Santa Maria é o atual arroio Cadena; o "Bacacahy-mirim" passou a chamar-se Arenal; e o Araricá é o atual Vacacaí-Mirim. O próprio mapa levantado em 1800 por Francisco Chagas Santos, engenheiro da Demarcação de Limites entre terras de Espanha e Portugal, elucida eventuais pendências geográficas, fornecendo, inclusive, o posicionamento exato do "Acampamento da Expedição" (Ver Figura 5).

Numa zona vasta e então despovoada, importa analisar-se os motivos que poderiam ter levado o sargento-mor Joaquim Félix da Fonse$\mathrm{ca}^{82}$ a escolher a área do atual centro urbano de Santa Maria para acampamento da Partida.

${ }^{82}$ Natural de Lisboa (1754), faleceu no Rio de Janeiro (125-1814). Tido como fundador de Santa Maria (BELTRÃO, R., 1979. Op. cit., p. 32), era o comandante da Partida portuguesa que, por ofício de 13-6-1797, assinado pelo Coronel Francisco João Róscio, recebeu ordem de deixar o povo de São João Batista para acampar junto à Guarda Portuguesa do Passo dos Ferreiros.
Situado próximo ao divortium aquorum das bacias do Uruguai e Jacuí, então limite entre as das duas coroas ibéricas na região, o "Rincão de Santa Maria" também distava menos de três léguas da "Guarda Portuguesa do Arroio dos Ferreiros" ${ }^{83}$, conforme recomendação expressa no ofício do Coronel Francisco João Róscio ao povoador de Santa Maria. ${ }^{84}$

Sob o nome de "rincão", fica implícito que a área era de campo nativo, isolado por cordões de matas. ${ }^{85}$ Situada no interior desse rincão, a

${ }^{83}$ No mapa de Chagas Santos figura como "Acampamento Portuguez”; pela posição, vê-se que ficava próximo da atual vila de Boca do Monte. (Ver Figura 5).

${ }^{84}$ Em ofício de 7-6-1797, o governador da Capitania do Rio Grande de São Pedro (Brigadeiro Sebastião Xavier da Veiga Cabral da Câmara) determinou ao $2^{\circ}$ Comisssário (Coronel Francisco João Roscio) que a Partida Portuguesa, após descer a "Serra de São Martinho do Monte Grande", deveria acampar numa distância máxima de duas ou três léguas da guarda avançada do Arroio dos Ferreiros (BELTRÃO, R., 1979. Op. cit. p. 27). Resta informar que esse curso d'água, situado a oeste da cidade, é atualmente mais conhecido como "arroio da Ferreira".

85 "Esta coxilha que é aqui de lombas baixas, próxima ao mesmo Araricá, mais livre de capões de mato, forma com as suas colinas laterais este Rincão de Santa Maria de 
coxilha correspondente ao atual centro urbano de Santa Maria é ponto relativamente elevado e, portanto, vantajoso para fins estratégicos -, além de distante de banhados e áreas inundáveis, motivo pelo qual era preferível ao Passo da Areia, escolhido para o acampamento da $1^{\text {a }}$ Partida, dez anos antes do povoamento (1787). Coberta de vegetação campestre em seu dorso, a coxilha escolhida também favorecia a instalação dos primeiros ranchos. Por fim, há que se salientar, no sítio em questão, a sua proximidade com as matas ciliares do arroio Cadena e tributários, que dissecam a área central de Santa Maria. Hoje extintas pela urbanização, ao tempo do povoamento tais matas foram certamente valiosas aos povoadores pelo suprimento de dois elementos indispensáveis: água e lenha. Destas matas ciliares, a do Itaimbé ganhou notoriedade como palco da "Lenda de Imembuî", imortalizada por Cezimbra Jacques $^{86}$ e João Belém ${ }^{87}$.

\section{LITERATURACITADA}

ART, H. W. Dicionário de ecologia e ciência ambiental. São Paulo: Companhia Melhoramentos, $1998.583 \mathrm{p}$.

AVÉ-LALLEMANT, R. Viagem pelo sul do Brasil no ano de 1858. Rio de Janeiro: Instituto Nacional do Livro, 1953. v. 1.398 p.

BELÉM, J. História do município de Santa Maria 1797-1933. Porto Alegre: Livraria Selbach, 1933. $277 \mathrm{p}$.

comprimento de duas léguas e dois terços, e de largura de duas e meia" (Belém, J. História do Município de Santa Maria. Porto Alegre: Selbach, 1933. p. 16-17). Como informação, resta esclarecer que o "Araricá" é o atual Vacacaí-Mirim

${ }^{86}$ Militar e escritor santa-mariense (13-11-1849; Rio de Janeiro, 28-7-1922). A lenda de Imembuí foi incluída em "Assumptos do Rio Grande do Sul", obra vinda a lume em 1912 (Porto Alegre: Officinas graphicas da Escola de Engenharia, p. 110-133).

${ }^{87}$ Natural de Porto Alegre (4-3-1874), João Belém faleceu em Santa Maria (24-6-1935). Incluída em sua "História do Município de Santa Maria 1797-1933" a "Lenda da Imembuî" pode ser encontrada pelo leitor entre as páginas 5 e 9.
BELTRÃO, R. Flórula fanerogâmica do município de Santa Maria, RS, Brasil (Primeiro Catálogo). Boletim do Instituto de Ciências Naturais da Universidade de Santa Maria, Santa Maria, n. 1, p. 3-63, 1962.

BELTRÃO, R. Flórula fanerogâmica do município de Santa Maria, RS, Brasil (Primeiro Suplemento). Boletim do Instituto de Ciências Naturais da Universidade de Santa Maria, Santa Maria, n. 2, p. 115-151, 1965.

BELTRÃO, R. Cronologia histórica de Santa Maria e do extinto município de São Martinho. Canoas: La Salle, 1979. $582 \mathrm{p}$.

BRENA, D. A., LONGHI, S. J. Inventário Florestal. In: ITAQUI, J. (org.). Quarta Colônia: Inventários Técnicos. Santa Maria: Condesus, Quarta Colônia, 2002. $256 \mathrm{p}$.

BRUXEL, A. O gado na antiga Banda Oriental do Uruguai. Pesquisas, São Leopoldo, Série História, n. 13, p. 13-14, 1960.

CABRERA, A. L., WILLINK, A. Biogeografia de América Latina. Washington: Secretaria General de la Organización de los Estados Americanos, 1973. 350 p.

CÂMARA, S. X. da V. C. da, SALDANHA, J. de. Diário Resumido e Histórico. $1^{\mathrm{a}}$ Divisão da demarcação d'América Meridional. Anais da Biblioteca Nacional, Rio de Janeiro, v. 51, p. $167-$ 301, 1938.

CUNHA, A. G. da. Dicionário histórico das palavras portuguesas de origem tupi. São Paulo: Melhoramentos/Edusp, 1989.357 p.

DOCCA, S. Vocábulos indígenas na geographia riograndense. Revista do Instituto Histórico e Geográphico do Rio Grande do Sul, Porto Alegre, I e II trimestre, p. 3-168.

FURTADO, N. F. Vocábulos indígenas na geografia do Rio Grande do Sul. Porto Alegre: Pontifícia Universidade Católica, 1969. 193 p.

GRAELL, F. O passado missioneiro no diário de um oficial espanhol. Santa Cruz do Sul: Edunisc, 1998. $105 \mathrm{p}$.

IHERING, H. Von. A distribuição de campos e mattas no Brazil. Revista do Museu Paulista, São Paulo, v. 7, p. 125-178, 1907.

ISABELLE, A. Viagem ao Rio Grande do Sul (18331834). Porto Alegre: Martins Livreiro-Editor, 1983. $164 \mathrm{p}$. 
JAEGER, L. G. Os bem-aventurados Roque González, Afonso Rodríguez e João Del Castillo, mártires do Caaró e Pirapó. Porto Alegre: Selbach, $1951.368 \mathrm{p}$.

KAUSEL, E. Los tipos de Mirtáceas extranjeras conservados en el Herbario de Santiago. Revista Universitaria (Universidad Católica de Chile), Santiago, v. 35, n. 1, p. 135-146, 1950.

LEITE, P. F. As diferentes unidades fitoecológicas da região sul do Brasil - Proposta de classificação. Cadernos de Geociências, Rio de Janeiro, n. 15, p. 1-191, 1995.

LINDMAN, C. A. M. A vegetação no Rio Grande do Sul (Brasil Austral). Porto Alegre: Echenique Irmãos \& Cia., 1906. 356 p.

JACQUES, J. C. Assumptos do Rio Grande do Sul. Porto Alegre: Officinas graphicas da Escola de Engenharia, $249 \mathrm{p}$.

MARCHIORI, J. N. C. A vegetação no sul da América: perspectiva paleoflorística. Ciência \& Ambiente, Santa Maria, n. 24, p. 5-24, 2002.

MARCHIORI, J. N. C. Fitogeografia do Rio Grande do Sul: Campos sulinos. Porto Alegre: EST, 2004. $39 \mathrm{p}$.
MARTIUS, C. F. von. A viagem de von Martius. Flora Brasiliensis. Rio de Janeiro: Editora Index, 1996. 140 p.

PORTO, A. História das Missões Orientais do Uruguai. Porto Alegre: Selbach, 1954. v. 1. 434 p.

RAMBO, B. Estudo comparativo das leguminosas riograndenses. Anais Botânicos do Herbário “Barbosa Rodrigues”, Itajaí, n. 5, p. 107-184, 1953.

REITZ, R., KLEIN, R. M., REIS, A. Projeto Madeira do Rio Grande do Sul. Sellowia, Itajaí, n. 34-35, p. 1-525, 1983.

ROMARIZ, D. de A. Aspectos da vegetação do Brasil. São Paulo: edição da autora, 1996.60 p.

SCHMIDT, M. V. C., MARCHIORI, J. N. C., NASCIMENTO,A. R. T., ALVAREZFILHO, A. Relações histórico-florísticas, fitossociologia e aspectos ecológicos do alecrim (Holocalyx balansae Mich.) em floresta primária, na região de Formigueiro. Ciência e Natura, Santa Maria, n. 15, p. 161-183, 1993.

VELOSO, H.P., GÓES-FILHO, L. Fitogeografia brasileira. Classificação fisionômico-ecológica da vegetação neotropical. Boletim Técnico, Radambrasil. Ser. Vegetação, Salvador, v. 1, p. 1-80, 1982. 